\title{
SAMUEL JOHNSON'S CHILDHOOD ILLNESSES AND THE KING'S EVIL
}

\author{
by \\ LAWRENCE C. MCHENRY, JR. AND RONALD MAC KEITH
}

\begin{abstract}
'HERE is a brave boy,' proclaimed George Hector, * when he brought Samuel Johnson into the world. From this moment and throughout most of his childhood, young Sam was harassed by a variety of afflictions that troubled his daily existence, but did not prevent him from eventually becoming one of England's outstanding literary figures. Samuel Johnson's adult illnesses and the history of his childhood have been described by many writers, but no separate work is available on his childhood medical history. The purpose of this paper is to describe Johnson's childhood medical disorders and their consequences.

The principal source of information on this period in Johnson's life is from an autobiographical sketch, An account of the life of Dr. Samuel Johnson from his birth to his eleventh year, written by himself. Johnson apparently called this his 'Annals' and his two principal biographers, Boswell and Hawkins, did not know of its existence. This was written when he was 55 years old and was 'among the mass of papers which were ordered to be committed to the flames a few days before his death.'** Johnson's 'Annals' gives a record of his early affections, but it contains a rather questionable medical implication that has been perpetuated as fact. This is that Johnson developed tuberculosis during the first few weeks of his life. We propose to point out that this is unlikely and to show that it is much more probable that he developed tuberculosis later, when he was about two years old.
\end{abstract}

* George Hector (b. circa 1678), whom Johnson called 'a man mid-wife of great reputation', was a surgeon in Lichfield. Hector had a large practice as a parish doctor, attending various ills, setting broken bones, treating scrofulous tumors, etc. ${ }^{27}$ His home was less than one hundred yards away from the Johnsons. He was an uncle of Johnson's schoolfellow and life-long friend, Edmund Hector, a Birmingham surgeon. It was unusual in the early eighteenth century for childbirth to be assisted by a 'man' mid-wife. His mother's age and difficult labour probably prompted Hector's attendance during the birth. In previous times ladies-in-waiting or mid-wives were usually present during labour and birth. Obstetrics as an accepted speciality for physicians did not begin until the late eighteenth century with the publication of Smellie's Midwifery (1752) and William Hunter's the Gravid Uterus (1774).

** This manuscript diary was preserved from the flames by Johnson's Negro servant Francis Barber, and subsequently purchased from Barber's widow by Richard Wright, a surgeon in Lichfield. Wright published Johnson's Account in London in 1805. (An Account of the Life of Dr. Samuel Johnson, From His Birth To His Eleventh Year, Written By Himself. To Which Are Added, Original Letters To Dr. Samuel Johnson, By Miss Hill Boothby: From the MSS. preserved by the Doctor; and now in Possession of Richard Wright, Surgeon; Proprietor of the Museum of Antiquities, Natural and Artificial Curiosities \&c. Lichfield., London: Printed For Richard Phillips, No. 6, Bridge-Street, Blackfriars; By Nichols and Son, Red Lion Passage, Fleet Street, 1805.) This is among the rarest Johnsonian items and was the second work to be published on Johnson by a medical man. The first was by Anderson (1795). Wright was also the proprietor of a museum in Lichfield that was originally founded by his grandfather, Richard Green, an apothecary. Little is known of either Wright or Green or of their medical careers. Their museum ceased to exist and its contents were dispersed a few years after Wright published the Account. The original manuscript was sold as part of a lot by Sotheby's in 1819 and this is the last record of its location. ${ }^{16}$ It could still be in existence. 


\section{Samuel Johnson's Childhood Illnesses}

Johnson's medical history literally begins with his birth. We learn of his difficult episode from the first paragraph of his 'Annals' ${ }^{16}$

7 September 1709, I was born at Lichfield. My mother had a very difficult and dangerous labour, and was assisted by George Hector, a man mid-wife of great reputation. I was born almost dead and could not cry for some time. When he had me in his arms, he said, 'Here is a brave boy.'

The exact nature of his mother's prenatal history and of her labour are not available, but, being forty years old, she was, in the obstetrician's phrase, an elderly primipara. In such mothers there is a greater incidence of the complications of pregnancy and of difficulties in labour. At the labour there is also increased danger to the infant and a variety of possible complications. Since Johnson was almost born dead and did not cry for some time, he may well have had a certain degree of postnatal asphyxia, and Hector probably carried out resuscitative measures. The life of the newborn must have been considered precarious, for he was christened that same night in his mother's bedroom. Hector was indeed right in saying that it was a brave boy who came through such a difficult birth. It has been suggested ${ }^{6}$ that the psychological and movement disorders, which came later in Johnson's childhood, were due to birth trauma and cerebral anoxia. This has been discussed elsewhere, ${ }^{20},{ }^{25}$ with the conclusion that there is little evidence that Johnson had any neurological sequelae, such as cerebral palsy from his difficult birth, though it is possible that as a result he had an increased liability to develop neurotic disorder.

Since his middle-aged mother had not had previous children and had had a difficult labour, she was probably in no condition to nurse her new baby. So, at his father's insistence, the infant was placed out to a wet-nurse. This was not uncommon in the eighteenth century, and the wet-nurse, who was usually between twenty and thirty years of age, was chosen for her good health after she had demonstrated that she had an abundance of good milk. ${ }^{15}$ Young Sam was taken to George Lane, a five minute walk from his home, to be nursed by Joan Marklew, the wife of a Johnson family servant, who had nursed her own son during the previous eighteen months. ${ }^{28}$ The infant usually remained with the wet-nurse for six to nine months, but Johnson was brought home after ten weeks. In his 'Annals' Johnson describes his experience at the Marklews and mentions his first childhood disorder inferring that the scrofula* he had when he was two years old began at this time:

My mother visited me every day, and used to go different ways, that her assiduity might not expose her to ridicule; and often left her fan or glove behind her, that she might have a pretence to come back unexpected; but she never discovered any token of neglect. Dr. Swinfen** told me that the scrofulous sores which afflicted me proceeded from the bad humours of the nurse, whose son had the same distemper, and was likewise short-sighted, but both in a less degree. My mother thought my diseases derived from her family.

* Scrofula is derived from the Latin scrofula, diminutive of scrofa, breeding sow, supposed to be liable to the disease (O.E.D.). "A constitutional disease characterized mainly by chronic enlargement and degeneration of the lymphatic glands. Also called King's Evil and Struma". The etymology of scrofa is dubious; possibly it is akin to ypapw in the sense of grave or burrow, hence the scraping or burrowing animal. Struma from struo, I heap up, was also employed by eighteenth-century writers. ${ }^{8,}, 24$

** Samuel Swinfen, M.D. (1679-1736) lectured for some time on grammar at Oxford before he graduated in medicine in 1712 from Pembroke College. He practised in Lichfield and had "considerable reputation in his profession as a physician'. Before his marriage he lived with the Johnson family. His daughter, Mrs. Desmoulins, became a boarder in Johnson's household when he lived later in London. 


\section{C. McHenry, Jr., and R. Mac Keith}

Here it was discovered that my eyes were bad; and an issuef was cut in my left arm, of which I took no great notice, as I think my mother has told me, having my little hand in a custard. How long this issue was continued I do not remember. I believe it was suffered to dry when I was about six years old.

In ten weeks I was taken home, a poor, diseased infant, almost blind.

I remember my aunt Nath. Ford told me, when I was about . . . years old, that she would not have picked such a poor creature up in the street.

Here Johnson has said that what Dr. Swinfen told him convinced him that the scrofulous sores (which we know were present when he was two and a half years old) began when he was with Mrs. Marklew. At this time the poor diseased infant also had bad eyes and was almost blind. From Swinfen's remark and the fact that he later developed tuberculous lymphadenitis and partial blindness, Johnson and subsequent writers assumed that he contracted tuberculosis during the first few weeks of his life while he was nursing with Joan Marklew. It was further assumed that his eye trouble in the early weeks of his life was a manifestation of an early infection with tuberculosis. This is most likely not the case, for reasons set forth below and also because tuberculosis in this age group is nearly always fatal.

Although the nature of various infectious diseases has changed in the two and a half centuries since 1709 , it is doubtful that tuberculous infections in early infancy are more severe now than they were in Johnson's day. From the experience of various physicians, ${ }^{26}$ not only is tuberculosis rare in this age group but when it does occur, it almost certainly leads to miliary tuberculosis and death (in the absence of modern drug therapy). In the last century Treves ${ }^{33}$ found that when such cases did occur under the age of one year, they were usually severe and often fatal. Had Johnson had tuberculosis during his first few weeks of life, he most likely would not have survived. His ocular affection in early infancy was probably a non-specific ophthalmia neonatorum or conjunctivitis and blepharitis. According to Miller $^{26}$ tuberculous infections of the eyes are never seen at this age.

Hence, we may assume that Swinfen and Johnson himself may have been in error in attributing the tuberculous sores in his neck to his stay at Mrs. Marklew's. Johnson tells us of the inaccuracy of attempts to recall details of a childhood 50 years past. After the sentence describing the placing of the issue in his arm he writes: 'It is observable, that having been told of this operation, I always imagined that I remembered it, but I laid the scene in the wrong house. Such confusions of memory I suspect to be common'.

Also Johnson was not certain of the time when his Aunt Ford told him that she

f Issue, from the Latin ex eo meaning 'to go out', was a small incision in the skin that was made with a needle or cautery. It was made on the same side of the body as the lesion being treated. In Johnson's case his left eye was involved, hence the issue was made in his left arm. Issues, similar to setons, were used to stimulate the discharge of noxious humours from the body to withdraw the disease. Issues or setons in the arm were recommended by both Boerhaave 30 and Sydenham ${ }^{31}$ for the treatment of ocular inflammation. The issue was kept open by a small foreign body such as a pea (Paré used a small gold ball). Rolleston ${ }^{29}$ says Johnson was treated by a seton in the neck, but gives no reference for his statement. Since Johnson had draining neck lesions, it is doubtful that another chronic lesion was induced. MacAdam ${ }^{16}$ comments that Johnson's incision was kept open with a horsehair or threads. A seton could be so kept open by threading through a fold in the skin. However, an issue (Johnson uses the word issue twice and knew the difference between a seton and an issue) needs a round rather than thread-like object to keep it open. 


\section{Samuel Johnson's Childhood Illnesses}

would not have touched such a poor diseased creature in the street. He did not seem to recall when she told him this, for he leaves a blank space before 'years'. She could have been referring to his initial illness in infancy. On the other hand, Aunt Ford probably would not have picked up a poor diseased creature with draining scrofulous sores in his neck either.

Johnson could also well be wrong on the date the issue was placed in his arm. Placing a ten-week old infant's arm in custard while an issue was being cut would be of little comfort to such a small patient. A hand in custard, however, might distract a one or two year old child. We must assume then that the placing of the issue, a common treatment for bad eyes or scrofula, was carried out at a later date, but before he was finally taken to be touched by the Queen.

Johnson was born during the autumn, and his early tender months of life were spent during the cold English winter of the Midlands in a home that was possibly draughty and cold. Children born this time of the year are more difficult to raise than those born in the spring. A whole variety of disorders could have affected the young infant, including disturbed nutrition from poor feeding by his wet-nurse. In all probability Johnson had some of the common infections of this age group. Such infections may recur over long periods and produce great debility. Like many young English infants of the period Johnson probably had recurrent infections of his nose and throat. Although we have little information on his earliest illness at Mrs. Marklews, it is more likely to have been such ailments than tuberculosis.

Apparently Johnson completely recovered from the illness that he developed at Mrs. Marklew's. The only other disorder we know of during his first year is recorded in the second paragraph of his 'Annals:' 'In a few weeks an inflammation was discovered on my buttock, which was at first, I think, taken for a burn; but soon appeared to be a natural disorder. It swelled, broke, and healed'.

This was probably a simple abscess following an ammoniacal scalding of the skin from a diaper rash. Although solitary tuberculous lesions may occur without an apparent connection between lymphatics or bone, the absence of tuberculous infection elsewhere and the apparently quick resolution rule out a tuberculous abscess, which would have lasted a long time. Again Johnson could be wrong about the date of his abscess, which may have occurred later in his childhood.

\section{THE KING'S EVIL}

From the available evidence it appears to us that Johnson developed tuberculous lymphadenitis, or the King's Evil, when he was two years old. In his 'Annals' he wrote 'In the second year I know not what happened to me.' We do know that when he was two and a half years old he was taken to London to be touched by Queen Anne. Boswell ${ }^{5}$ wrote that Scrofula or the King's Evil 'terribly afflicted his childhood.' Dr. Swinfen said that he never knew any child reared with such difficulty.

Tuberculous infections of the cervical lymph nodes develop within a few months of the infection. We can assume, therefore, that Johnson developed his primary infection about the time he was two years old and not earlier. He also had concomitant difficulties with his eyes, for at some time during his second year he was taken twenty miles to Worcester to see a noted physician and oculist, Dr. Thomas 


\section{C. McHenry, Jr., and R. Mac Keith}

Attwood. ${ }^{7,}{ }^{28}$ We do not know the reason he was taken, nor Attwood's opinion or recommendations. It is possible that the issue was placed in his arm at this time. Within the next several months, however, he was taken to be touched, a form of treatment that was used for fully developed scrofula that did not respond to the usual general and supportive treatment.

Scrofula usually develops around the age of five years, but occasionally cases occur at two or three years of age. ${ }^{15}$ The primary focus of infection is in the oral or nasopharyngeal cavity, and the infection may be quite small and hard to detect. Initially it would be difficult to differentiate tuberculous lymphadenopathy in childhood from the commoner enlargement of the cervical lymph nodes caused by other bacterial infections. The source of infection was usually the milk of tuberculous cows. Although this is the common route of infection, it is possible for the infection to be passed from another person. ${ }^{26}$ From the fact that Mrs. Marklew's son subsequently developed scrofula and short sight, which in later years prevented him from earning a living, we might presume that she, as Swinfen suggested, was the source of the disease, but not during the period of wet-nursing. Since there were no other cases of tuberculosis in the Johnson family, he must have contracted the disease outside his family. The only acquaintance who also had the disease that we know of was Mrs. Marklew's son. Johnson tells us that he used to frequent the Marklew's house on George Lane 'when I was a bigger boy, and eat fruit in the garden, which was full of trees.' But tuberculosis of the lymph nodes which we may presume Mrs. Marklew's son had, is not infectious. On balance it is more probable that Johnson contracted tuberculosis from infected cow's milk taken during the second year. In 1922 in his article on Johnson, Treves ${ }^{34}$ said he believed that Johnson became infected through the milk of a tuberculous cow, 'that being the theory favoured at the present day.'

\section{THE ROYAL TOUCH}

Other than the visit to Dr. Attwood and the placement of the issue in Sam's arm, there is no record of other forms of treatment of his scrofula. Heberden ${ }^{12}$ advised burnt sponge, sal sodae, issues and perpetual blisters as the principal treatment of scrofula. As late as the 1880s a seton was still recommended as being applicable to large tuberculous swellings, acting to effect suppuration in the body to bring about its elimination. ${ }^{33}$ Johnson's issue in his arm was therefore probably a treatment for his scrofula, as well as his inflamed eyes. However, the most effective treatment was, at that time, considered to be Royal touch. Johnson himself, nearly fifty years later in his Dictionary ${ }^{17}$ defined the 'King's Evil' as 'a scrofulous distemper, in which the glands are ulcerated, commonly believed to be cured by the touch of the King.'

When all other measures had failed to cure young Sam's scrofula, Sir John Floyer,* a celebrated Lichfield physician, advised the family to take Sam to London for the Royal touch.${ }^{16}$ So in March 1712, Johnson, then thirty months old, and his mother set out on the two to three day coach journey to London so that the boy could be

* Sir John Floyer (1649-1734), former physician to Charles II was the first physician to count the pulse for which he constructed a special watch (The Physician's Pulse Watch, 1707). His Touch-Stone of Medicine (1687) dealing with the medical values of plants as judged by their taste and smell, was published by Johnson's father. Floyer wrote the first treatise on diseases of old age (Medicina Gerocomica, 1724). In his later years Johnson referred to Floyer's Treatise on the Asthma 1698."4 


\section{Samuel Johnson's Childhood Illnesses}

touched by the Queen. Johnson used to talk of this episode 'very frankly'. ${ }^{5} \mathrm{He}$ remembered being sick with a violent cough on the coach trip to London. Brain ${ }^{2}$ suggests that he might have had whooping cough. Treves ${ }^{33}$ points out, however, that scrofulous children often develop a troublesome cough on very trifling exposure.

Historically, touching or stroking for various diseases, primarily scrofula, originated with the ancient gods who performed miraculous cures by touching patients. Touching became the prerogative of the King, but was also practised by others.* Once the monarch was anointed he was considered the 'Christ of the Lord,' hence, having divine power, so that when he touched a sick person, God healed them. ${ }^{14}$ In England the practice began with Edward the Confessor and continued with interruptions to the reign of Queen Anne, who was encouraged to practise the art to demonstrate the divine right of the Stuarts. The ceremony was held for the last time in England by Queen Anne on 27 April 1714, three months before her death. ${ }^{14}$ She considerably shortened and altered the ceremony, but it consisted essentially of the same form throughout the ages. The ceremony opened with a Collect from the Communion Service and was followed by the Gospel from St. Mark with some versicles and the Lord's Prayer. Following this, those to be touched were brought by the surgeons one at a time to kneel before Queen Anne, who laid her hands upon them. She then took the touch-piece from the Clerk of the Closet and placed it on a white silk ribbon around the person's neck. At the same time the Chaplain turned towards the Queen and said 'God give a blessing to this work and grant that these sick persons, on whom the Queen lays her hands, may recover, through Jesus Christ our Lord.' After all were touched the Chaplain said a final versicle to which the sick responded, ${ }^{8,14}$

Prior to the journey to London Johnson's parents had to obtain a Parish certificate with a statement from the local physician, in this case probably Dr. Swinfen or Sir John Floyer, that Sam did have the King's Evil and that he had not been touched before. One might speculate whether a record was preserved of Johnson's certificate in the Lichfield parish. After Sam and his mother arrived in London, he had to be taken to be inspected by the court surgeon to further verify the nature of the disease. Then the day before Sam was touched his mother presented his certificate to an office in Whitehall and obtained their entry ticket. On 30 March 1712, she took him to St. James' Palace. Some two hundred persons were present to be touched that day.8, 14 After Queen Anne had touched him, she presented the touch-piece (Figure 3.) to the sick child. Being asked if he could remember the ceremony and Queen Anne, he replied, 'He had a confused, but somewhat a sort of solemn recollection of a lady in diamonds and long black hood' and had a vivid recollection of a boy crying in the palace. ${ }^{13}$

The touch-piece possibly originated as presentation from the monarch of alms to the sick. As time passed, the medal became more of a token or memento of the

* One such lay 'stroker', Valentine Greatraks (1629-1683), achieved great fame with his miraculous cures by stroking. ${ }^{8}$ No quack, attributing his power to the workings of God, Greatraks touched before King Charles II, as well as patients furnished by physicians. A book, Wonders no Miracles, bitterly attacked Greatraks who replied with a work addressed to the great Robert Boyle. A copy of Wonders no Miracles ${ }^{19}$ with Johnson's signature on the title page is in the Welloome Historical Medical Library, but nowhere in his writings is there mention of Greatraks, nor Johnson's thoughts on stroking. Thomas Tyers ${ }^{13}$ thought that cure of Johnson's scrofula would even be 'beyond the stroking power of Greatrix'. 


\section{C. McHenry, Jr., and R. Mac Keith}

occasion. The touch-piece Johnson received originated as a coin, the Golden Angel, worth $6 s .8 d$. ordered to be struck by Edward IV in 1465. It was the smallest of the gold coins, and was used during the succeeding reigns of Henry VI, Edward V, and Richard III. Henry VII issued a Golden Angel, and used it in the ceremony of healing. The original coin derived its name from the figure on the obverse (the front, or principal surface of a coin bearing the principal image of inscription) of the Archangel Michael piercing the dragon and surrounded by the inscription 'Edward. Dei-Gra. Rex. Et.-Franc.' On the reverse was a ship with its mast in the form of a cross surmounted by sunrays, and surrounded by the legend 'Per Crucem Tua.' 'Salua-NosRedempt' (By thy Cross, save us Redeemer Christ). ${ }^{8}$

The Queen Anne touch-piece that Johnson received is larger than its predecessors, measuring 0.85 inches in diameter. On the obverse is a ship sailing before the wind and the inscription, ANNA. D:G.M.Br. F: ET.H. REG. (Anne by the Grace of God, Queen of Great Britain, France, and Ireland). The reverse shows the Archangel Michael slaying the dragon and the inscription, SOLI, DEO. GLORIA (To God alone the glory). This latter inscription changed from the original on the gold Angel, and indicates that the work of healing is that of God alone and is His glory.

Johnson wore his touch-piece around his neck all his life, but we hear nothing of it or other such pieces in his writings or biographies. Upon his death his touch-piece passed into the possession of the Rev. John Taylor, canon at Westminster and Chaplain to the Dukes of Devonshire. ${ }^{27}$ A friend since their boyhood days in Lichfield, Taylor conducted Johnson's funeral service as a final act of fidelity. Johnson, during his frequent visits to the Midlands, often stayed with Taylor at Ashbourne, where more than once Boswell joined them.

In 1788, four years after Johnson's death, Taylor died, bequeathing Johnson's touch-piece to the Duke of Devonshire who was an ardent collector of coins and medals. In 1844 at a sale in London in the Sale Rooms of Christie and Manson, St. James's Square, the collections of the Duke of Devonshire were sold. The Devonshire collection was purchased by many buyers, including Edward Hawkins, a renowned collector who purchased Johnson's touch-piece for his own collection. Sixteen years later in 1860 the touch-piece was sold to the British Museum. ${ }^{22}$ In 1885 Hawkins $^{10}$ published Medallic Illustrations of the History of Great Britain and Ireland to the Death of George II. In volume II, pages 242-43, is the first recorded description of Johnson's touch-piece. In Plates of Medallic Illustrations of the History of Great Britain and Ireland (1909) the touch-piece is pictured as number 4 in plate CXVII.

Included with the touch-piece at the present time in the British Museum are two small round papers or tickets that are reproduced for the first time in Figure 4. One is a winged lion, the symbol AV or Au, for gold, and 'Dr. Johnson's TouchPiece.' On the other is written in faded ink, 'The identical piece given by Queen Anne to Dr. Johnson, 1712, see Boswell, E. H.' The initials, E. H., at the bottom, almost lost from being torn off, are those of Edward Hawkins.

In Johnson's case, as with others, the Queen's touch was of little benefit. As Crawfurd ${ }^{8}$ says, he carried with him to the grave abiding testimony of Anne's ineffectual handiwork. With the failure of Queen Anne's touch, Johnson's scrofulous 


\section{Samuel Johnson's Childhood Illnesses}

glands were finally surgically incised for drainage. He was "badly operated upon for the ulcers of his neck' and the under part of his face was seamed and disfigured by the operation. ${ }^{5}$ Surgical incision of tuberculous glands was not generally recommended, and Heberden ${ }^{12}$ suggested that the glands be allowed to ulcerate and drain spontaneously 'without the help of a knife or caustic.' Richard Wiseman, $\nmid$ who represented the best surgical opinion of his day, recommended three types of treatment for scrofula - the first being a proper diet; second, the application of pharmacy according to the habit of the body, e.g., for the phlegmatic-purging; and the third, application of externals to suppurate or extirpate the glands. Treves, ${ }^{33}$ over a century and a half later, believed that excision of glands in children should be regarded as the last resource. Today it is often used but only under specific circumstances. ${ }^{26}$ Perhaps in Johnson's case Swinfen or Floyer recommended lancing of the glands. The disease usually runs a natural course beginning with swelling beneath the jaw and along the side of the neck. Ulceration and spontaneous drainage of the glands occur in a few months and drainage persists in a chronic form for four to five years with drying up of the sores between the seventh and tenth years. ${ }^{15}$, ${ }^{33}$ From a remark of his friend, Edmund Hector, it would appear that Johnson's draining abscess had healed by the time he came to school at the age of eight years when he "had the scars on his neck." His scrofulous abscesses could have healed as early as the sixth year when the issue in his arm was allowed to dry. His disease lasted about four or five years, a frequent clinical course for tuberculous cervical lymphadenitis.

The vivid accounts of Johnson's appearance by his many admirers usually mention the scars. Boswell ${ }^{5}$ said that the scars 'greatly disfigured a countenance naturally harsh and rugged.' Bishop Percy ${ }^{13}$ tells us however: 'Johnson's countenance was not so harsh and rugged as has been misrepresented, and no otherwise disfigured by the King's Evil than its having a scar under one of his jaws, where some humour had been opened, but afterwards healed.'

Although several of the pictures that were made of Johnson portray his visual difficulty, the scars of his scrofula are usually not seen. In one portrait ${ }^{3}$ (Figure 4.), however, by a physician, Richard Blagden,* the scars on the left side are definitely shown. The scrofulous scars are even more apparent in a bust made from a mask of Johnson's head and shoulders that was taken after his death (Figure 5.).** As can

+ Richard Wiseman (1622-1679) gave an authentic account of the 'King's Evil' in his Eight Chirurgical Treatises (1719). A skilful operator, he held the same position in English surgery of his day that Sydenham did in the practice of medicine. Of the 900 technical terms of medicine and related subjects in Johnson's Dictionary, over 300 were taken from Wiseman's Treatises. ${ }^{34}$

* Richard Bragg Blagden (1753-1837), was a doctor of medicine who practised in Petworth during the last fifty years of his life. He was also an amateur artist. The picture of Johnson was probably taken from a print by Thomas Trotter, but Blagden's picture shows the scars of Johnson's scrofula more obviously than the original by Trotter. It is not known whether in his youth Blagden met Johnson, but his medical training must have influenced his picture since the scars are apparent.

** An original copy of this bust has been preserved by the Royal Literary Fund, Ludgate Hill, London. ${ }^{21}$ The death-mask itself was ordered taken by Sir Joshua Reynolds and several busts were made from the mask. This is the only bust known to be extant. This bust is of medical interest for several reasons. Not only does it show the original scars of Johnson's scrofula, but also a droop to the right lower face can be seen. This probably occurred at the time of Johnson's stroke on 16 June 1784, six months before his death. 24 This particular bust was owned by William Cruikshank (17451800), Johnson's surgeon. In 1844 Cruikshank's daughter, Mrs. A. Thomas, gave the bust to her son-in-law. Mr. William Hutchins. Twenty years later in $1864 \mathrm{Mr}$. Hutchins presented the bust to the Royal Literary Fund where it resides today. Two copies of the bust were taken by the National Portrait Gallery in 1878. 


\section{C. McHenry, Jr., and R. Mac Keith}

be seen, the scars are apparent on both sides of his neck, but are much deeper and more prominent on the left, the side on which he was operated.

\section{JOHNSON'S VISUAL DIFFICULTY}

Soon after his birth it was discovered that Johnson's eyes were bad. The poor diseased infant was almost blind and at ten weeks he was taken home from the Marklew's. Although originally considered a tuberculous infection, the initial bout of eye difficulty that afflicted the young infant during his first few weeks of life was probably a non-specific ophthalmia neonatorum. This is an infection, usually pyogenic, of varying degrees of severity. It is commonly contracted from the mother during the delivery process. The infection is often due to gonococcus, but there is no reason to suppose there was gonorrheal infection in Johnson's family. Symptoms are variable but generally consist of swelling of the eyelids, chemosis, conjunctivitis, and drainage of pus. The course of the disease is variable, depending on the cause and treatment. In cases not due to gonococcus the course is benign with recovery in several weeks. ${ }^{15}$ Johnson presumably recovered from this attack of ophthalmia neonatorum, for surely, if it had persisted and he had not been able to see during his earliest months, this episode would have been vivid enough to have been recalled by his family or in his 'Annals.'

The next reference we have to a visual disorder was during Johnson's second year when he was taken to the oculist. About this time, rather than previously, he contracted the tuberculous infection, which resulted in his scrofula. The association of eye disorders with scrofula was frequent. In the eighteenth century Heberden ${ }^{12}$ found that the 'eyelids are often inflamed and ulcerated in the scrofula.' In the next century Treves $^{32}$ wrote that ophthalmic afflictions, mainly phlyctenular ophthalmia are 'more common in the strumous than in any other class of individuals, and may be almost considered as peculiar to the scrofulous.' Even today ${ }^{23}$ it is recognized that phlyctenules occur in debilitated children, and 'in those suffering from tuberculosis or the so-called tuberculous diathesis.' Treves ${ }^{34}$ believed, from what he knew of the common eye troubles of tuberculous children, that Johnson had a tuberculous inflammation of the conjunctiva and corneas of his eyes. Beattie, ${ }^{1}$ who gives a thorough ophthalmological opinion on Johnson, was of a similar opinion that it was justifiable to suppose Johnson's disorder was a phlyctenular conjunctivitis, possibly with a complicating keratitis (inflammation of the cornea). Johnson himself further suggested that tuberculous origin of his ocular difficulty when he included a note from Wiseman's surgical Treatises as the only addition to his definition of the 'King's Evil' in his Dictionary:17 'Sore eyes are frequently a species of the King's Evil, and take their beginning from vicious humors inflaming the tunica adnata.'

Boswell $^{5}$ believed that the scrofula 'damaged his visual nerves.' Hawkins ${ }^{11}$ was in agreement to the scrofulous origin and, referring to Johnson's left eye, said he 'never remembered to have enjoyed the use of it.'

In tuberculous inflammation of the eye small collections of lymphoid tissue (called phlyctenules), accumulate on the conjunctivae (tunica adnata) and cornea producing phlyctenular keratoconjunctivitis. The phlyctenules may ulcerate and cause the brilliant surface of the cornea to become scarred, giving it a dull ground-glass appearance. 


\section{Samuel Johnson's Childhood Illnesses}

As the years pass, the dulled corneal surface may clear to some extent with enlargement of the visual field. The corneal scarring or opacity can be patchy or quite small (called a nebula) and scarcely apparent to an observer. The nebula may still cause severe visual disturbance on account of the resulting diffusion and irregular refraction of the light rays. Limited vision can be obtained through the unscarred portion, if the individual holds objects closer to the eye for a clearer definition. ${ }^{23}$ In Johnson's case corneal scarring probably destroyed enough central vision to make him essentially blind in the left eye. However, enough peripheral vision remained to keep the eye in good alignment, since a divergent strabismus with outward drifting of the eye did not develop. 1

Although it does appear that Johnson had damage to his eyes with residual blindness in his left eye, he did not have a noticeable corneal opacity or leucoma. Boswell ${ }^{5}$ says that his eyes were alike in appearance. Mrs. Thrale, ${ }^{13}$ an acute observer, said the defect was not observable and that his eyes were wild and piercing and of a light grey colour.

Along with ocular inflammation and blindness in one eye Johnson had further childhood visual difficulties that were considered due to myopia or near-sightedness. Beattie $^{1}$ suggests that he may have had myopic astigmatism.* Visual impairment delayed his starting school until he was eight years old, and then he had to have a servant to conduct him there. ${ }^{5}$

\footnotetext{
One day, when the servant who used to be sent to school to conduct him home, had not come in time, he set out by himself, though he was then so near-sighted, that he was obliged to stoop down on his hands and knees to take a view of the kennel before he ventured to step over it. His schoolmistress, afraid that he might miss his way, or fall into the kennel, or be run over by a cart, followed him at some distance. He happened to turn about and perceive her. Feeling her careful attention as an insult to his manliness, he ran back to her in a rage, and beat her, as well as his strength would permit.
}

Johnson mentioned feeling awkward about his bad eyes to the extent that when he was nine years old he would skip church in order to go in the fields to read. Defective sight prevented him from enjoying the common sports, and he used to go to the fields to read even up to the age of fourteen years. ${ }^{5}$ Johnson's great difficulty in reading most likely led him to memorize whatever he read. Later in life his nearvision was never adequate. His wig was often singed by a candle held too close while he read. To see the titles of the books in Dr. Burney's library his eyelids almost touched their backs. Mrs. Montagu spoke of his 'squinting look', and he is shown squinting in the Reynolds' portrait of 1769 (Figure 1), a habit myopic persons often cultivate to improve their visual acuity.** The Reynolds' portrait of 1775 and a Northcote portrait (Figure 2) show him holding a folded book close to his face. When he saw the former he told Mrs. Thrale, "he would not be known to posterity

\footnotetext{
* Beattie ${ }^{1}$ wonders if Johnson used glasses since uncomplicated myopia could have been corrected by spectacles which were in use at this time. Beattie believes it inconceivable that Johnson, who had discussed the use of lenses with George III, did not know about the use of concave glasses for myopia. Johnson, therefore, probably did not have ordinary axial myopia, but a high degree of myopic astigmatism which could not be corrected by the optical knowledge of the time.

** It should be pointed out that in the eighteenth century squinting was not synonymous with strabismus, as it is in modern medical circles. Even today in South East London squint commonly means to look with your eyes screwed up and half shut.
} 


\section{C. McHenry, Jr., and R. Mac Keith}

for his defects only,' adding that Reynolds, 'could paint himself deaf if he chooses, but I will not be blinking Sam.'13 He defined 'blink' in his Dictionary ${ }^{17}$ as 'to see obscurely', a 'blinkard' being one who had bad eyes. The severity of visual impairment is vividly described by Miss Reynolds, ${ }^{13}$ Sir Joshua's sister, who has given one of the most complete pictures of Johnson's appearance and habits.

Dr. Johnson's sight was so very defective that he could scarcely distinguish the Face of his most intimate acquaintance at a half yard's distance from him, and, in general, it was observable that his critical remarks on dress, etc. were the result of a very close inspection of the object.

Bishop Percy ${ }^{13}$ attributed Johnson's manner of writing to visual impairment:

He was so extremely short-sighted, from the defect in his eyes, that writing was inconvenient to him; for whenever he wrote, he was obliged to hold the paper close to his face. He, therefore, never composed what we call a foul draft . . . but used to resolve the subject in his mind . . . (and then wrote out the entire essay).

Brain, ${ }^{2}$ on the basis of Mrs. Thrale's description of Johnson's eyes, does not accept the attribution of Johnson's blindness to tuberculous keratitis but believes that Johnson's poor vision was due to myopia of sufficient severity to render one eye amblyopic (blind) and the vision in the other very poor.

Since Johnson wrote that in his forty-sixth year his sight was restored to him, Rogers $^{29}$ and Rolleston ${ }^{30}$ suggested that as he got older presbyopia mitigated his myopia, thus restoring his sight. Both are mistaken about Johnson's reference to the recovery of his vision, for the restoration of his sight he refers to in 1756 was following a bout of ocular inflammation with partial blindness in his good right eye.* His left eye never recovered vision.

Although he held objects close and squinted, Johnson's distant vision was, at least at times, good, making simple myopia unlikely as the full explanation. Madame D'Arblay noted that he was able to see the hour on a Lichfield clock. During their travels in the Scottish Highlands, Boswell observed to him that a certain mountain resembled a cone. With astuteness Johnson corrected his companion by showing that it was indeed pointed on the top, but that one side of the mountain was longer

* In early February 1756, Johnson had a bout of inflammation in his right eye that made him unable to read and lasted a week or two. Thankful for the recovery of his vision, on 15 February he composed a prayer, 'When my eye was restored to its use': 'Almighty God, who has restored light to my eye, and enabled me to persue again the studies which thou hast set before me; teach me by the imminution of sight, to remember that whatever I possess is thy gift, and by its recovery, to hope for thy mercy ... Four days later the inflammation came again so that he could write very little. After this relapse he recovered rapidly as compared to a more severe attack seventeen years later.

In April 1773, Johnson had an episode of fever and chills which lasted two or three days subsiding with a 'regular crisis'. Referring to Celsus he believed it was a continuous rather than an intermittent fever. Two days after his fever subsided he felt at night 'a pain in my eye which was the next day inflammed to a great degree'. Joseph Baretti described this episode in a letter to Mrs. Thrale on 5 June 1773: 'I went yesterday to dine at the Royal Academy where I met with Mr. Mudges (Dr. John Mudges (1721-1793), a distinguished surgeon), who told me that he never said he apprehended any Gutta Serena (a form of amaurosis in which vision is totally lost) in Mr. Johnson's eye, but that he thought that eye looked very bad, and that unless Mr. Johnson took greatest care to have the inflammation removed the danger of losing his sight was very great'. To remove the inflammation Johnson was 'bled very copiously twice' and took 'thirteen purges in fifteen days'. After a week there was less pain in his eye ('eye is easier') and the photophobia which accompanied the inflammation was subsiding ('bears light better'). On 20 and 21 June he composed a poem on the recovery of the use of his eyes. This attack of ocular inflammation, which left Johnson completely sightless for a period of time, was possibly a dendritic ulcer which came on after his fever. ${ }^{2}$ 


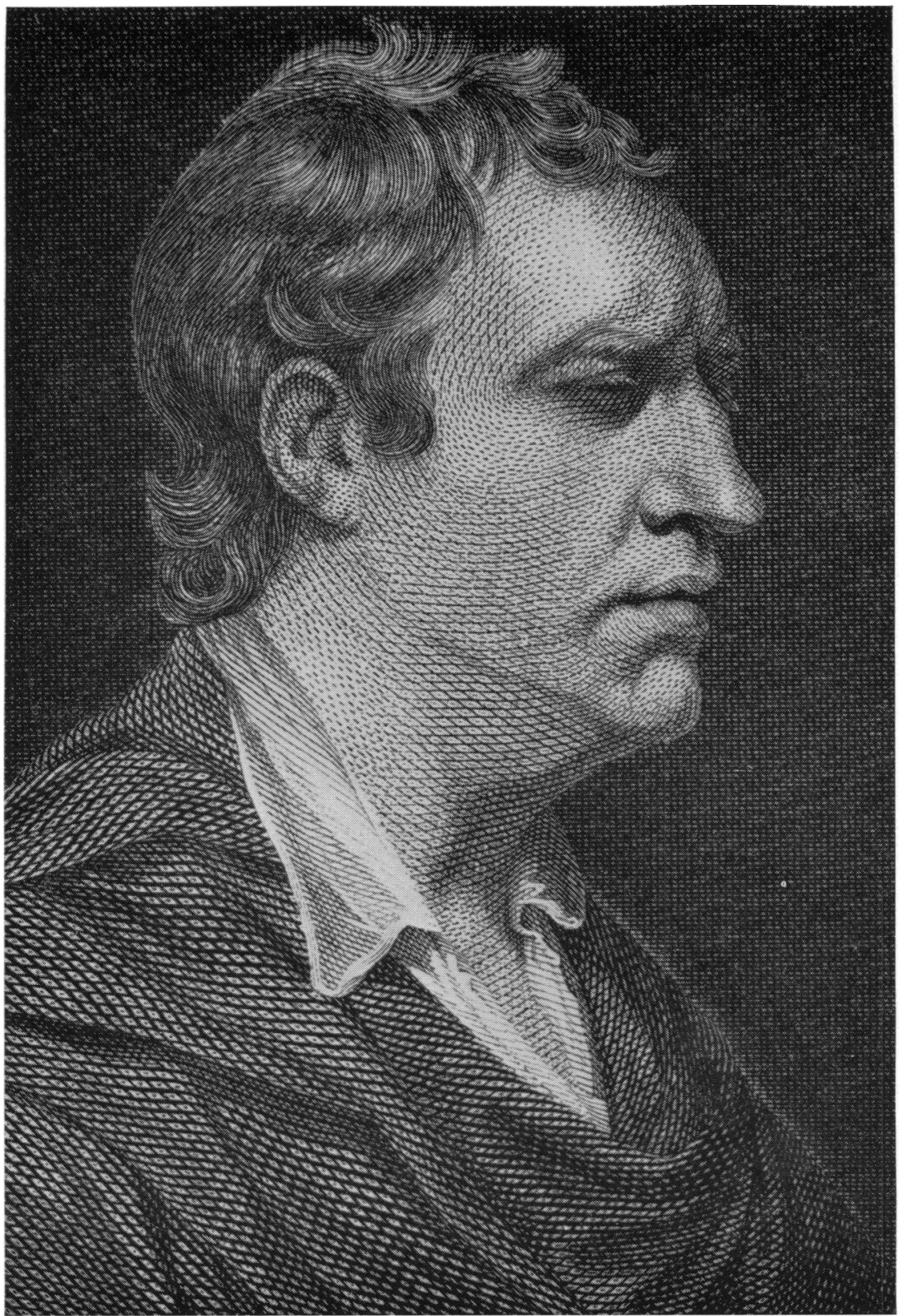

Figure 1. A mezzotint by James Watson, dated 1770 after the 1769 picture by Sir Joshua Reynolds, showing Johnson squinting. 


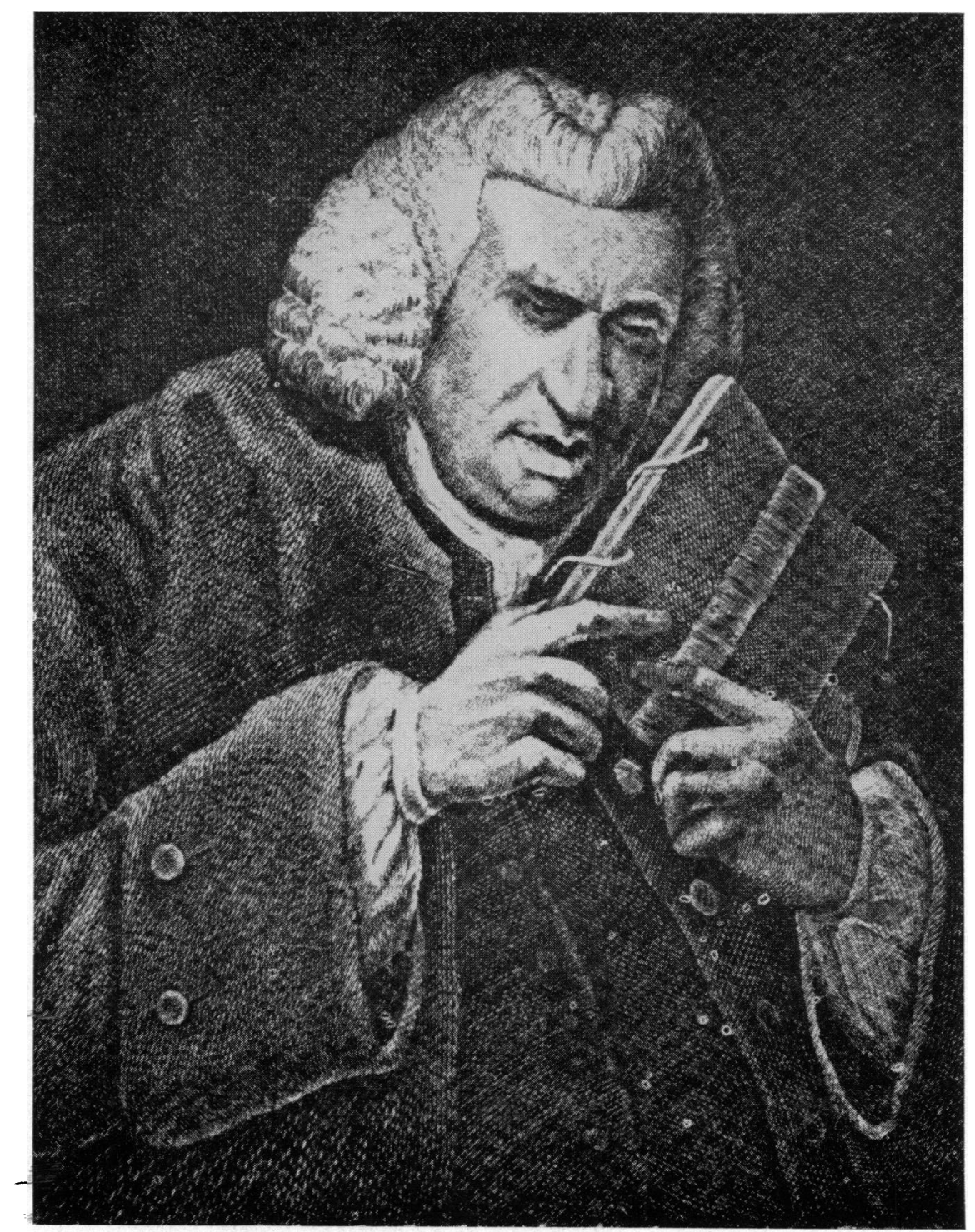

Figure 2. From an engraving by De Clausen 1813 after a portrait by James Northcote, R.A., showing Johnson squinting, "holding a book close to his face at an awkward angle. His figure is ungainly and the whole picture is not pleasing.' 5 

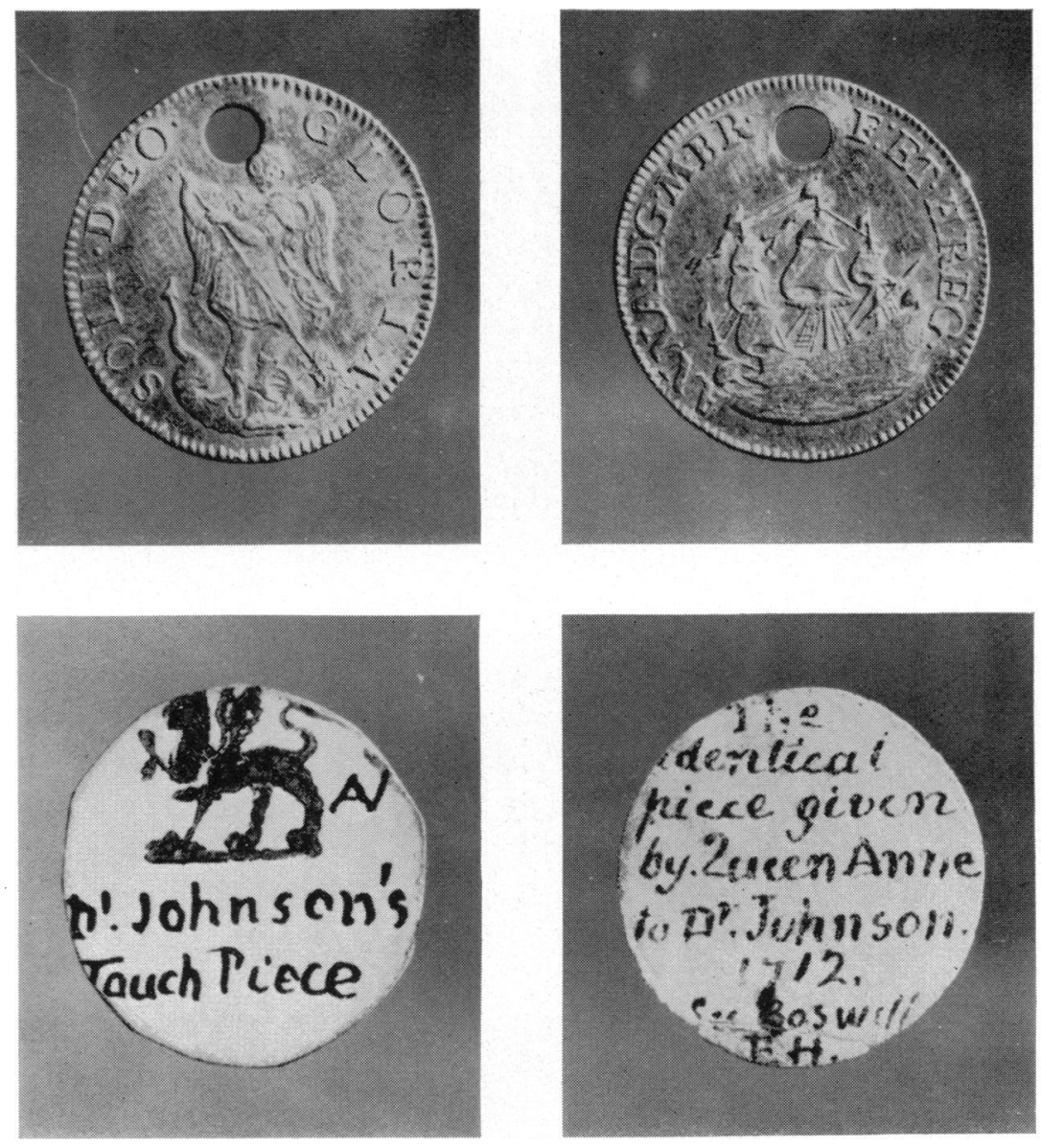

Figure 3. Samuel Johnson's touch-piece and two small 'tickets' in the collections of the British Museum. The obverse of the touch-piece, on the right, shows a ship sailing before the wind with the inscription ANNA. D:G.M. Br. F:ET.H. REG (Anne by the Grace of God, Queen of Great Britain, France, and Ireland). The reverse, on the left, shows the Archangel Michael slaying the dragon with the inscription SOLI. DEO. GLORIA (To God alone the glory). The 'ticket' on the left shows a winged lion and the symbol AV, or Au for gold and 'Dr. Johnson's TouchPiece.' On the 'ticket', on the right, Edward Hawkins, 'E.H.' has written, 'The identical touch-piece given by Queen Anne to Dr. Johnson. 1712. See Boswell.' 


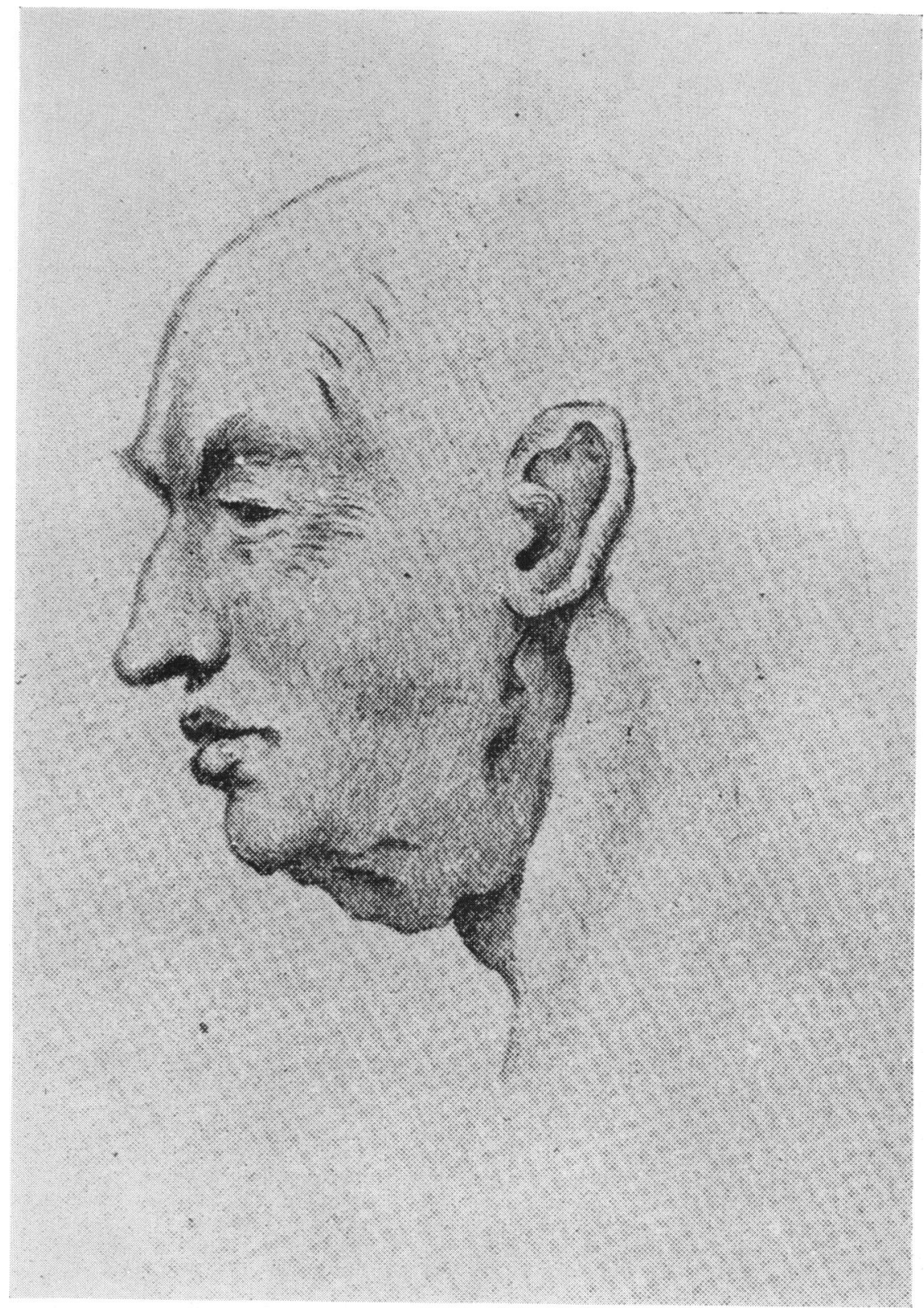

Figure 4. A pen-and-ink drawing by Richard B. Blagden, M.D., 1774, said to have been taken from life (Broadley, 1910); this sketch shows the scars of the scrofula on the left in a similar manner to their appearance on the left side of Johnson's death-mask bust. 


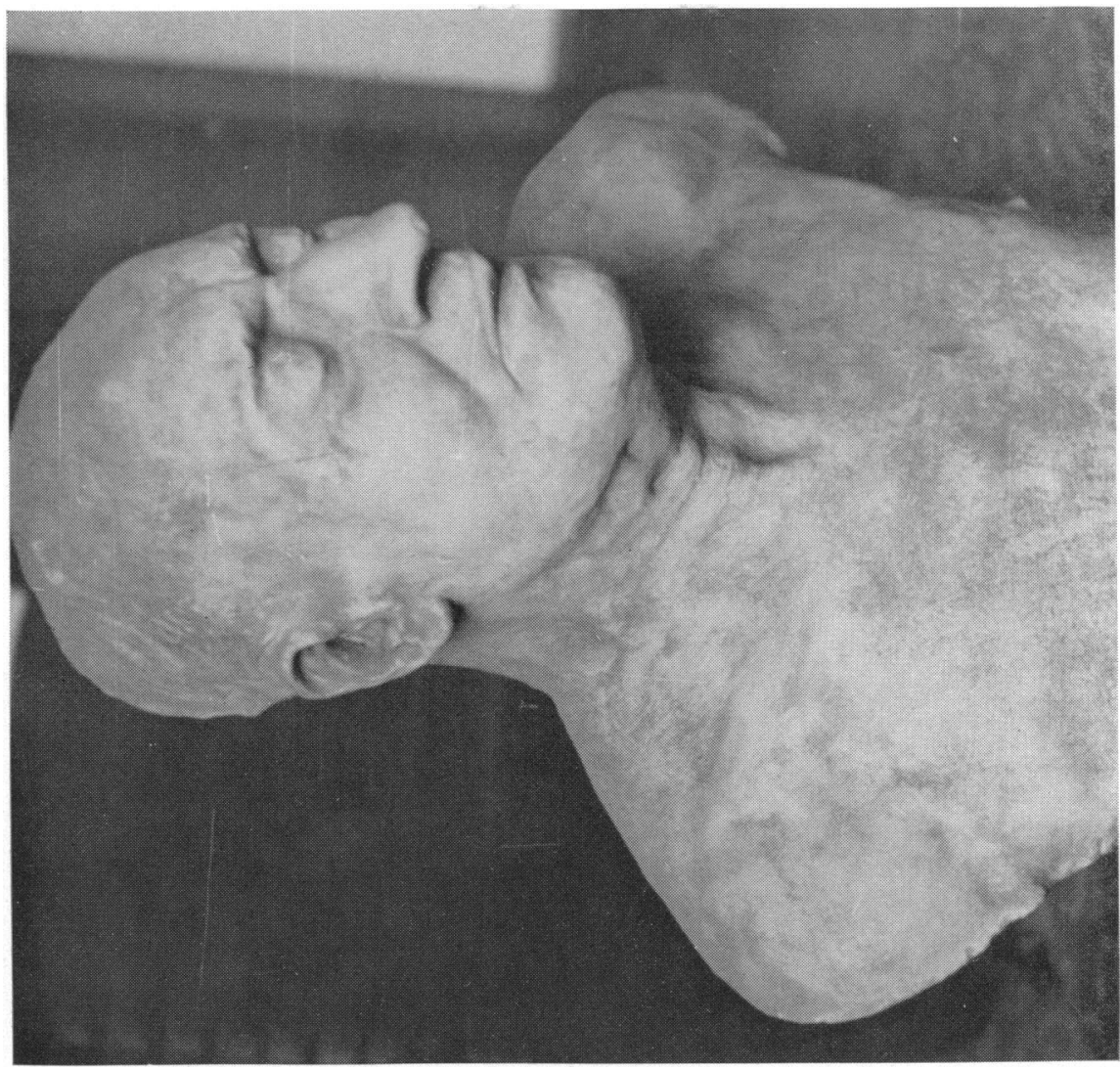

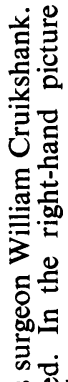

鱼惫

그웡웡

उ。

व०

3ิ

त $0^{\circ}$

胥望㐘

응을

o

s.

330

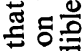

을

응믕

옹욣

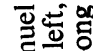

हूँ

등 웡

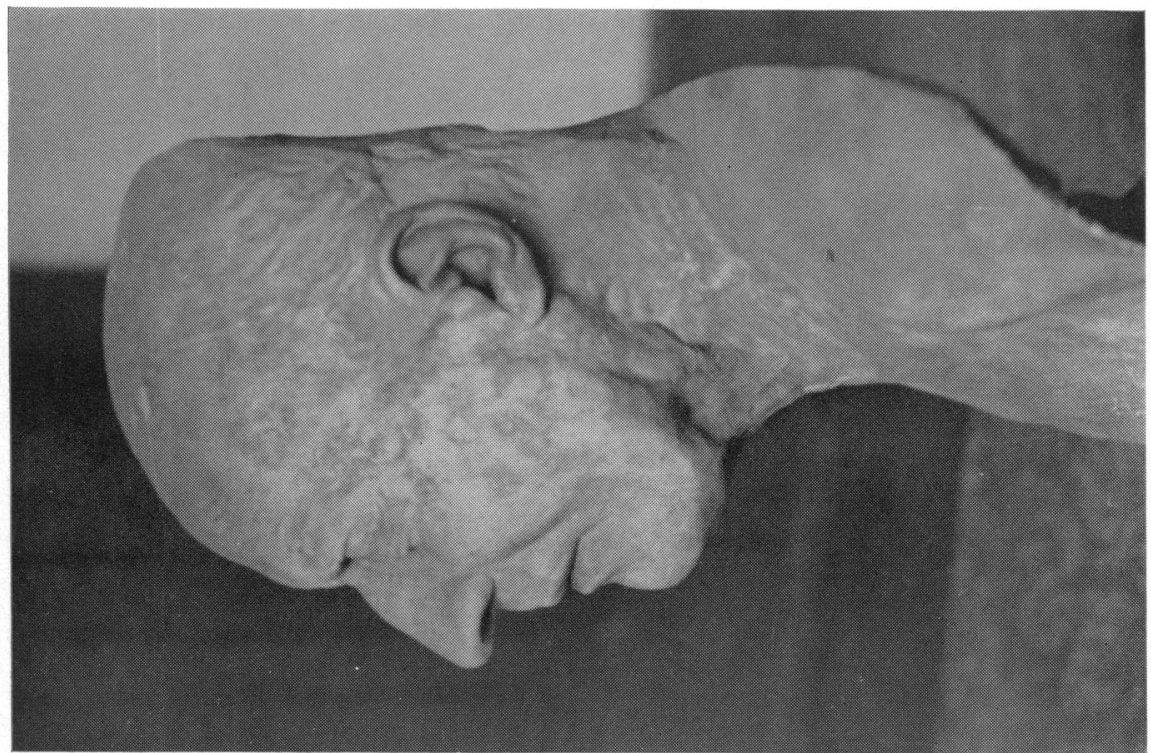

蒙专莺

등

है

ส

馬

త્긍

电

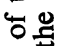

n

客 온

䒠哭

뒁

일 


\title{
Samuel Johnson's Childhood Illnesses
}

than the other. In his travels to France Johnson accurately described the animals and birds he saw in the zoo and aviary. Similarly, the dress of various ladies rarely failed to rouse from him a comment of one sort or another. He told Garrick, 'I'll come no more behind your scenes, David, for the silk stockings and white bosoms of your actresses excite my amorous propensities.'

\section{OTHER ILLNESSES AND JOHNSON'S HEARING}

As well as residual ocular damage probably from tuberculous phlyctenules, Johnson's hearing was impaired. Many, including Johnson himself, attributed this to his original scrofula. Mrs. Thrale ${ }^{13}$ wrote that the scrofulous evil did 'irreparable damage to the auricular organs, which never could perform their function since I knew him.' As Heberden ${ }^{12}$ noted inflamed eyes 'have sometimes . . . been joined with cutaneous eruptions, and purulent discharge from the ears.' Treves ${ }^{33}$ says otorrhea is one of the commonest earliest manifestations of scrofula. He adds, this in turn may lead to otitis media, chronic suppuration and hearing loss. Miller ${ }^{26}$ notes that infection of the middle ear may result from tuberculous extension via the Eustachian tube from the nasopharynx. Deafness is an early symptom, being observed in older children, but often missed in infants.

The exact age at which Johnson partially lost his hearing is not known, but as well as being blind in his left eye, he became deaf in his left ear. There are at least a dozen references in his own writings to his difficulty in hearing. Miss Reynolds ${ }^{13}$ believed that perhaps his unaccommodating manners could be partially ascribed to his defective hearing, "which not only precluded him from the perception of the expressive tone of the voices of others, but from hearing the boisterous sound of his own.' His deafness was the reason that his seat at St. Clement Danes Church was at the east end of the north gallery, immediately above the pulpit. Later in his life this amusing event occurred: ${ }^{5}$

\begin{abstract}
After having talked slightingly of music, he was observed to listen very attentively while Mrs. Thrale played on the harpsichord, and with eagerness he called to her, 'Why don't you dash away like Burney?' Dr. Burney upon this said to him, 'I believe, Sir, we shall make a musician out of you at last.' Johnson with candid complacency replied, 'Sir, I shall be glad to have a new sense given to me.'
\end{abstract}

During his final illness when the Rev. Holle was preaching, his 'hearing not being quite perfect', he more than once interrupted Mr. Holle with 'Louder, my dear Sir, louder, I entreat you, or you pray in vain.' His dislike of the theatre and music has been attributed to his poor hearing, as his dislike of the visual arts to his impaired vision.

Johnson's only other childhood illness that is recorded was casually mentioned in a diary kept during his journey to North Wales. ${ }^{16} \mathrm{He}$ wrote 'my father went to the fair when I had the smallpox.' This reference is to his father's trip to the fair at Chester, probably to sell books. Johnson's note is the only information we have about his smallpox. Apparently it was a mild case (if it was not in fact chickenpox mistakenly diagnosed as smallpox), leaving no facial scars or pockmarks, for Percy ${ }^{13}$ wrote that his face was clear and his complexion good. Later in life when he mentioned vaccination for smallpox he did not refer to his own case. He thought highly of 


\section{C. McHenry, J., and R. Mac Keith}

inoculation or vaccination, however, saying that it saved more lives than war destroyed. ${ }^{5}$

No further illnesses in Johnson's childhood are recorded by him or his various biographers. He possibly had other childhood diseases that were not specifically mentioned. Measles, mumps, whooping cough, and chicken pox were well recognized childhood diseases and differentiated from various 'fevers.' ${ }^{12,}$ 20, 32

\section{ACKNOWLEDGEMENTS}

We wish to thank Mrs. Joan Martin of the Department of Coins and Medals of the British Museum for her assistance concerning Johnson's touch-piece. Photographs of the touch-piece are by the courtesy of the Trustees of the British Museum. Mr. John J. Broadbent, of the Royal Literary Fund, gave permission to photograph Johnson's death-mask. Grateful thanks are extended to Mr. Broadbent for this and for access to letters about the death-mask.

\section{REFERENCES}

1. Beattie, P. H., 'The ocular troubles of Dr. Johnson and Mr. Pepys', Proc. roy. Soc. Med., $1953,46,591-6$.

2. Brain, W. Russell, ‘A post-mortem on Dr. Johnson', Lond. Hosp. Gaz. 1934, 37, 225-30.

3. BroAdley, A. M., Dr. Johnson and Mrs. Thrale, London, Lane, 1910.

4. Brockbank, William, Ancient Therapeutic Arts, London, Heinemann, 1954.

5. Boswell, JAMES, Life of Johnson, together with Boswell's journal of a tour of the Hebrides and Johnson's diary of journey into North Wales, edited by G. B. Hill, revised and enlarged by L. F. Powell, 6 vols, Oxford, Clarendon Press, 1934-1950.

6. Chase, Peter, P., 'The ailments and physicians of Dr. Johnson', Yale J. Biol. Med., 1951, 23, 370-79.

7. Clifford, JAmes, L., Young Sam Johnson, New York, McGraw-Hill, 1955.

8. Crawfurd, Raymond, The King's Evil, Oxford, Clarendon Press, 1911.

9. GarRison, Firlding H., An introduction to the History of Medicine with medical chronology, suggestions for study and bibliographic data, 4th ed., Philadelphia, W. B. Saunders, 1929.

10. HaWkIns, EDWARD, Medallic Illustrations of the History of Great Britain and Ireland to the death of George II, vol. 2, pp. 242-43, London, British Museum, 1885.

11. HawkIns, SIR JoHn, The Life of Samuel Johnson, edited, abridged with an introduction by Bertram H. Davis, New York, Macmillan, 1961.

12. Heberden, William, Commentaries on the History and Cure of Disease, London, T. Payne, 1802.

13. Hill, George BirkBeck, Johnsonian Miscellanies, 2 vols., New York, Harper, 1897.

14. HuSSEY, EDWARD LAW, 'On the cure of scrofulous diseases attributed to the Royal Touch', Archaeol. J., Lond., 1853, 10, 187-211.

15. Holt, L. Emmett, The Diseases of Infancy and Childhood, New York, D. Appleton, 1898.

16. Johnson, SAmuel, Diaries, prayers, and annals, edited by E. L. MacAdam, Jr., with Donald and Mary Hyde, New Haven, Yale University Press, 1958.

17. Idem., Dictionary of the English Language in which the words are deducted from their originals and illustrated in their different significations, by examples from the best writers, 3rd ed., London, W. Strahan, 1765.

18. Idem., The Letters of Samuel Johnson with Mrs. Thrale's Genuine Letters to him, collected and edited by R. W. Chapman, 3 vols., Oxford, Clarendon Press, 1952.

19. LLOYD, D., Wonders no miracles: or Mr. Valentine Greatrak's gift of healing examined, upon occasion of a sad effect of his stroking, 7 March, 1665, at one Mr. Cressets house in Charter-House-Yard, in a letter to a Reverend Divine, living near that place, London, Sam Speed, 1666. 


\section{Samuel Johnson's Childhood Illnesses}

20. Mac KeIth, Ronald, 'Samuel Johnson, my patient', Oxf. Med. Sch. Gaz., 1959, 11, 4-12.

21. Idem., The Death-mask of Samuel Johnson, London, Johnson Society (in the press).

22. MarTin, JoAN, Personal communication.

23. May, Charles H., Manual of the diseases of the eye, edited, revised by Charles A. Perera, Baltimore, William Word, 1943.

24. MCHenry, LaWrence C., JR., Samuel Johnson's final illness and his 'Aegri Ephemeris'.

25. Idem., 'Samuel Johnson's tics and gesticulations', submitted for publication, J. Hist. Med.

26. Miller, F. J. W., TAYLOR, M. D., and Thomas, D. M. E., Tuberculosis in Children; evolution, control and treatment, Boston, Little Brown \& Co., 1963.

27. Reade, Aleyn L., Johnsonian Gleanings; Part III 'The Doctor's Boyhood', London, Privately Printed, 1922.

28. Idem., Johnsonian Gleanings; Part $\mathrm{X}$ 'Johnson's early life: the final narrative', London, Privately Printed, 1946.

29. ROGERs, B. M. H., 'The medical aspect of Boswell's Life of Johnson, with some account of the medical men mentioned in that book', Brist. med.-chir. J., 1911, 28, 280-310; $29,125-48$.

30. Rolleston, Sir Humphrey, 'Medical aspects of Dr. Johnson', Glasg. med. J., 1924, 110, 173-91.

31. SwIETEN, BARON van, Commentaries upon Boerhaave's aphorisms concerning the knowledge and cure of diseases, 18 vols., Edinburgh, Charles Elliott, 1776.

32. Sydenham, Thomas, The entire works of Dr. Thomas Sydenham, newly made English from the originals: wherein the history of acute and chronic diseases, and the safest and most effectual methods of treating them, are faithfully, clearly and accurately delivered, 5th ed., by John Swan, London, E. Newbury, 1769.

33. TreVes, Sir Frederick, Scrofula and its gland diseases, New York, Birmingham, 1882.

34. Idem., 'Samuel Johnson', Cassells' Magazine, 1924, pp. 38-44.

35. Wimsatr, W. K., JR., Philosophic words, a study of style and measuring in the Rambler and Dictionary of Samuel Johnson, New Haven, Yale University Press, 1948. 